\title{
Evaluation of Human Epidermal Growth Factor Receptor-2 in Iraqi Women with Breast Cancer \\ Hiba Hadi Rashid $(\mathrm{BSc})^{1}$, Walaa Najm Abood $(\mathrm{PhD})^{2}$ and Nameer Fadhel $\operatorname{Gaeb}(\mathrm{PhD})^{3}$ \\ Abstract
}

\begin{abstract}
Background:Breast cancer $(\mathrm{BC})$ is the most common malignancy in Iraqi women in the recent years. There are many indicated marker for detection $\mathrm{BC}$ and determination the development of the tumor stage, one of the most important marker is human epidermal growth factor receptor-2 (HER2).

Objective:To evaluation of serum and tissue HER2 levels among BC women and non BC women.

Patients and Methods: Preoperative blood samples were collected from breast cancer women. Patients were newly diagnosing and did not receive neither radiotherapy nor chemotherapy treatment preoperatively.For the control, blood sample was collected from non-breast cancer women. All blood samples subjected to determine the serum HER-2 level.

Results: A total of 52 patients with breast cancer and 30 of control were included in this study. The result showed increasing significant in serum concentration of HER-2 among BC patient compared to control and tissue her- 2 positive $\mathrm{BC}$ patient have significantly higher serum concentration of HER-2 compared to BC patients who were tissue her-2 negative $(16.23 \pm 10.37$ $\mathrm{ng} / \mathrm{ml}, 10.33 \pm 5.73 \mathrm{ng} / \mathrm{ml}$ ) respectively.

Conclusion: Serum HER-2 level was positively associated with tissue HER-2 level, for that is an important marker for diagnosis and monitoring BC progression.
\end{abstract}

Keywords: Breast cancer, serum HER2, tissue HER-2.

Corresponding Author: mastermedical55@gmail.com

Received: $11^{\text {th }}$ October 2018

Accepted: $18^{\text {th }}$ November 2018

${ }^{1,2,3}$ College of Medicine - University of Diyala - Diyala - Iraq.

\section{Introduction}

Breast cancer is the most common type of malignancy recorded in the cancer registries of almost all countries within the Eastern Mediterranean Region. In Iraq, the continuous rise in the incidence rate is associated with an obvious trend to affect premenopausal women [1]. The incidence of breast cancer appears to beincreasing worldwide [2]. Breast cancer is a multifactorial disease there are a number of risk factors that affected the probability of developing $\mathrm{BC}$; several factors like (gender, age, personal history, family history, early menarche and late menopause) are not modifiable.Other 
factors: postmenopausal obesity, use of postmenopausal hormones, alcohol consumption, physical activity, and smoking are modifiable risk factors [3].Human epidermal growth factor receptor-2 is more intensively studied in $\mathrm{BC}$ and other solid cancers Firstly identified by Schechter 1984 [4]. It is consisting of three principle domains the first is the extracellular ligand binding domain (ECD), the second, is the transmembrane domain (TMD) and the third, the intracellular tyrosine kinase catalytic domain (ICD) [5]. The ECD of the receptor protein can be cleaved from the cell surface by matrix metalloproteinase and then released into the blood [6]. The present study was undertaken with the aim to investigate the association of some demographic characteristics such as age, menopause state, family history and breastfeeding with the development of $\mathrm{BC}$ and explore the clinical utility of serum HER2/ neu estimation by ELISA in breast cancer patients and evaluate whether it could be used in place of FISH/IHC.

\section{Patients and Methods}

This case control study included 52 female patients with $\mathrm{BC}$ who underwent to either mastectomy or lumpectomy, their age range (25-78) years old and 30 of non BC women . This study was performed in Baghdad Teaching Hospital - Medicine City during period from September 2017 to March 2018. The diagnosis in each case was established by clinical diagnosis and confirmed by histopathological diagnosis. Patients were newly diagnosing and did not receive neither radiotherapy nor chemotherapy treatment preoperatively. After surgery and evaluation of sample pathology, benign cases were excluded. The result of tissue HER2 status obtained from patients' record. Five milliliters of peripheral blood were collected from all participants and put in a sterile test tube and after $30 \mathrm{~min}$ centrifuged at $3000 \mathrm{~g}$ for $10 \mathrm{~min}$ at room temperature. Serum samples were stored at $-20 \mathrm{C}$ till the time of the assay. After collection of all samples, to measure the serum HER2/ECD concentration, we used to enzyme-link immunosorbent assay method (Human receptor tyrosine-protein kinase erbB-2, ELISA kit catalogue number SL2747Hu, Sun long-Biotech/China).

\section{Statistical analysis}

The Statistical Package for the Social sciences (SPSS, version 14) was used for statistical analysis. Continuous variables are expressed as mean \pm standard deviation (SD). Chi- square was used for testing the deviation from Hardy- Weinberg equilibrium as well as for comparing between categorical variables. Student t-test and Mann Whitney U test were used to compare serum levels of sHER-2 between patients and controls

\section{Results}

Table (1) shows the demographic data of the study groups. Mean age of patients and control were 47.63 \pm 10.34 years and $49.3 \pm 11.95$ years respectively with no significant difference at $(\mathrm{P}<0.05)$. Also for menopause status, there was no significance difference in the frequency of premenopausal and postmenopausal status among patients 
and controls $(\mathrm{P}<0.05)$. Although patients had higher frequency for family history of BC than control (46.15\% versus $26.67 \%$ ), the difference did not reach a significant level $(\mathrm{P}<0.05)$. In contrast, breastfeeding differed significantly between patients and

Table (1): Baseline characteristics of the study population.

\begin{tabular}{|c|c|c|c|}
\hline Variables & $\begin{array}{c}\text { Cases } \\
52\end{array}$ & $\begin{array}{c}\text { Controls } \\
30\end{array}$ & P-value \\
\hline Age (years, mean \pm SD) & $47.63 \pm 10.34$ & $49.3 \pm 11.95$ & 0.509 \\
\hline $\begin{array}{l}\text { Menopausal status } \\
\text { Premenopausal } \\
\text { Postmenopausal }\end{array}$ & $\begin{array}{l}23(44.23 \%) \\
29(55.77 \%)\end{array}$ & $\begin{array}{l}13(43.33 \%) \\
17(56.67 \%)\end{array}$ & 0.937 \\
\hline $\begin{array}{l}\text { Family history } \\
\text { No } \\
\text { Yes }\end{array}$ & $\begin{array}{l}28(53.85 \%) \\
24(46.15 \%)\end{array}$ & $\begin{array}{l}22(73.33 \%) \\
8(26.67 \%)\end{array}$ & 0.077 \\
\hline $\begin{array}{l}\text { Breastfeeding } \\
\text { No } \\
\text { Yes }\end{array}$ & $\begin{array}{l}28(53.85 \%) \\
24(46.15 \%)\end{array}$ & $\begin{array}{l}6(20 \%) \\
24(80 \%)\end{array}$ & 0.002 \\
\hline
\end{tabular}

* Significant at $\mathrm{P}$ value $<0.05$

According to the employed ELISA technique, the mean serum concentration of HER-2 in BC patients and controls were $11.33 \pm 6.97 \mathrm{ng} / \mathrm{ml}$ (range 4.4-37.2 ng/ml) controls. Out of thirty healthy controls, 24 $(80 \%)$ have used to feed their child by breastfeeding. On the other hand, only 24 out of $52(46.15 \%)$ women with BC had such practice $(\mathrm{P}<0.05)$.

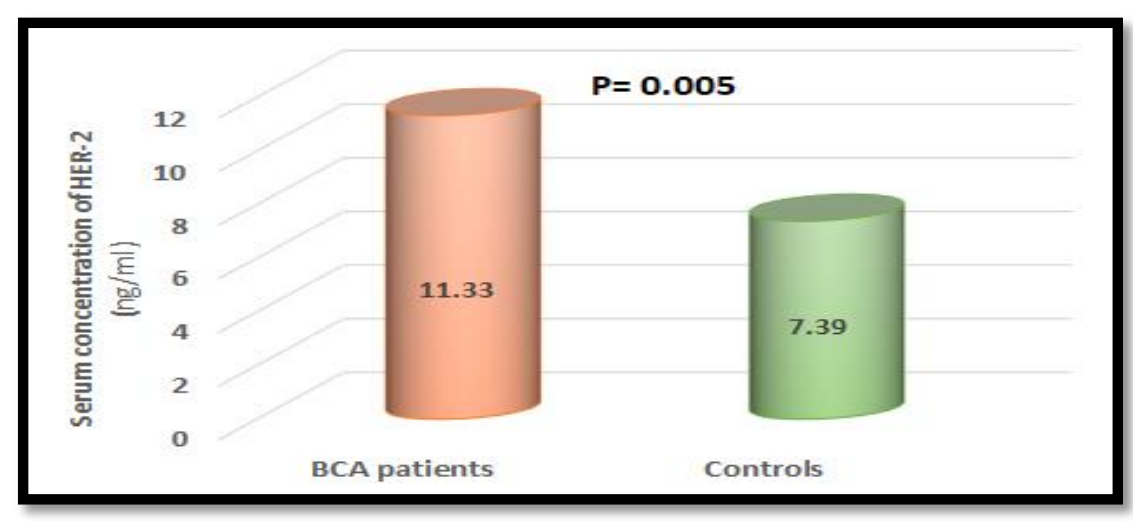

Figure (1): Serum concentration of HER-2 in BC patients and controls, Significant at $\mathrm{P}$ value $<0.05$.

Out of 52 BC patients, $9(17.31 \%)$ were tissue her-2 positive, while the other 43 $(82.69 \%)$ were tissue her-2 negative. Based and7.39 $\pm \quad \mathrm{ng} / \mathrm{ml}$ (range $0-13.4 \quad \mathrm{ng} / \mathrm{ml}$ ) respectively Figure (1). Statistical analysis showed highly significant difference $(\mathrm{P}<$ 0.05). 
were positive for serum HER-2, while there was none among control group positive for HER-2. Figure(2) illustrated the tissue her2 positive $\mathrm{BC}$ patients had higher serum concentration of HER-2 compared to BC patients who were tissue her2negative $(16.23 \pm 10.37 \quad \mathrm{ng} / \mathrm{ml} \quad$ versus $10.33 \pm 5.73 \mathrm{ng} / \mathrm{ml})$ with a significant difference $(\mathrm{P}<0.05)$.

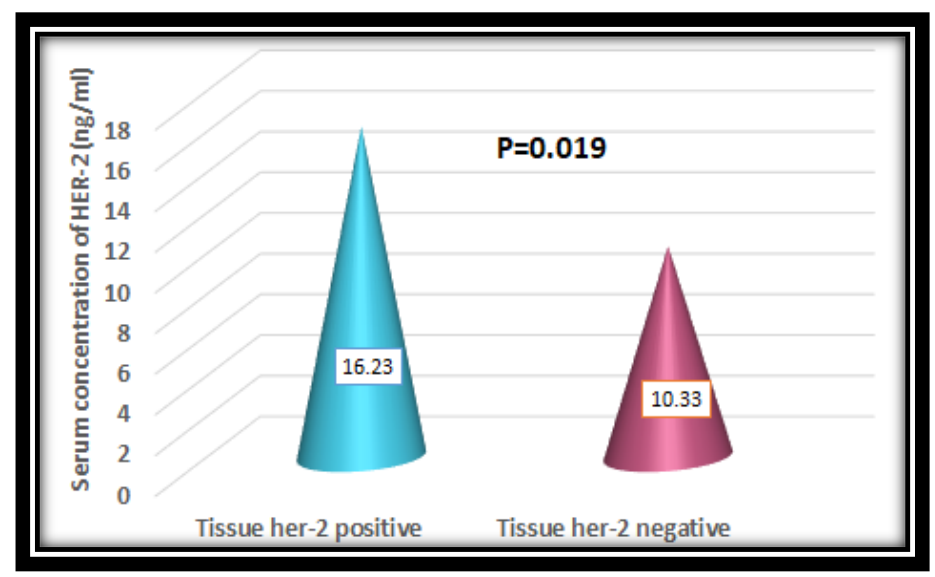

Figure (1): mean serum concentration of HER-2 in BC tissue her-2 positive and negative patients.

Significant at $\mathrm{P}$ value $<0.05$

\section{Discussion}

For age, women in control group were intentionally selected to match patients regarding age. Thus, no significant difference was found between the two groups. Otherwise age was frequently reported to be a risk factor for $\mathrm{BC}$ [7]. In a local study, a study carried out on 721cases with BC and found that age group (40-49) years were more susceptible to this malignancy [8]. Globally, found the peak age in which BC more prevalent in Asian countries was between 40 and 50 years. However, this age range is still lower than those observed in most developed countries like' USA, UK with a peak age between 60 and 70(9). These variations in incidence may be due to multiple factors, including decrease in birth rate, trends of breastfeeding, increase in the

age at first pregnancy, geographic variation, racial/ethnic background, genetic variation, lifestyle and environmental factors [10] [11]. Similar to age, the menopausal status shows no significant difference between patients and controls. This result does not agree with many other international studies. In Turkey found among 346 cases, (73.1\%) of women in post-menopausal situation had higher BC risk [12]. The risk of $\mathrm{BC}$ in women with menopauses after 55 is twice the risk than women with menopauses before 45 years old. Additionally, BMI may further have complicated the situation. The overweight during postmenopausal status has very important role in development BC. These variations between the current study and the other studies may be explained by the small 
sample size and ethnic background of current study compared with other studies [13].

Family history was frequently recorded to be significantly associated with $\mathrm{BC}$ in the life time. In the current study, the result was showing no significant difference in family history between $\mathrm{BC}$ patients and controls. This result is not in accordance with that of other international studies. In Palestine, has investigated the association of family history of $\mathrm{BC}$ with incidence of this malignancy among 140 Palestinian women as well as 163 healthy controls and reported that family history was strong risk factor for BC particularly at young age [14]. In Turkey, carryout a study on 172 patients with $\mathrm{BC}$ and 383 controls, and showed that family history of $\mathrm{BC}$ were significantly association with increased $\mathrm{BC}$ risk among Turkish women (OR=4.67, 95\% CI: 2.23- 9.76) [15]. These disparities between the current study and the other international studies may be explained by the small sample size of current study compared with other studies.

One of most important result in the current study was the inverse significant association between breastfeeding and $\mathrm{BC}$. This result is in accordance with result of another international studies. In Morocco enrolled 124 BC women and 148 age matched controls and in their study. They showed that breastfeeding for more than six months was significantly associated with decreased incidence of $\mathrm{BC}$ [16]. It seems that the duration of breastfeeding during overall lifetime has a very important role as a protective factor against BC. In a case-control study, in
Srilank a, reported that women who used breastfeeding for 24 months or more during life time had significantly lower risk of $\mathrm{BC}$ than those who breastfed for less than 24 months. Interestingly, there was $66.3 \%$ reduction in BC risk in women who breastfed for $12-23$ months, $87.4 \%$ reduction in $24-35$ months and $94 \%$ reduction in $36-47$ months [17]. However, some studies reported no association between breastfeeding and BC [18] [19].

Although the mechanisms are not entirely elucidated, there are many explanations for this protection role of breastfeeding. Firstly, lactation reduces estrogen and elevates prolactin levels which results in reduced cumulative exposure to estrogen [20]. Secondly, in women who are not breastfeeding, milk $\mathrm{pH}$ rises (becomes alkaline) compared to that from the breastfeeding women. The epithelial cells from an alkaline environment undergo several changes, among which hyperplasia, atypia, and increased mitotic activity [21]. These changes, and may be others, can progress to $\mathrm{BC}$.

The current study revealed a significantly higher serum sHER2 level BC patients than controls. In fact, elevated serum sHER-2 was frequently found in patients with $\mathrm{BC}$ as well as in patients with other cancers such as ovarian cancer, lung cancer, and prostate cancer [22]. In one study, about $11.4 \%$ of early patients with metastatic BC had elevated sHER-2 [23]. In another study, high levels sHER-2 was found in $18 \%$ of women 
with primary $\mathrm{BC}$ and in $46 \%$ of those with metastatic disease [24].

Soluble HER-2 is generated in two ways: the proteolytic cleavage, known as shedding of ECD [25] and by alternative initiation of mRNA translation [26]. As a considerable percentage of women with $\mathrm{BC}$ have amplification/overexpression of HER2, the current result is reasonable, because there is an increase in shedding of extracellular domain of this receptor into the plasma [27].

For serum concentrations of HER2 in BC tissue her2 positive and negative patients, the result of current study revealed tissue HER2 positive $\mathrm{BC}$ patients significantly higher than serum concentration of HER2 BC patients who were tissue her2 negative. This result comparable with that of other previous studies. In China measured the serum HER2 level in BC patients and found that the serum HER2 level measured by dot blot assay was significantly correlated with tissue HER2 status in BC patients( $\mathrm{p}=0.001)$, and also significantly correlated with HER2 level measured by ELISA $(\mathrm{P}=1.06 \times 106)$ [28]. In Korea reported out of 2862 cases of stage IIII primary BC patients, $24 \%$ were found to be tissue her 2 positive, and only $15 \%$ of these tissue positive patients had elevated sHER2[29].

Several studies have demonstrated that the proteolytic cleavage of HER2 results in the release of the extracellular domain of HER2 and the production of truncated cellassociated fragments, and supported the hypothesis that the truncated HER2 protein is associated with enhanced signalling activity and confers an adverse prognosis $[30 ; 31]$.

\section{Conclusions}

Serum HER-2 level was positively associated with tissue HER-2 level, for that is an important marker for diagnosis and monitoring BC progression.

\section{References}

[1]Alwan NA. Breast Cancer Incidence Among Iraqi Women Profiled, Breast Cancer News2010, American Association for Cancer Research. Site: www.AACR.org.

[2] Althius MD, Dozier JM, Anderson WF, Devessa SS, Brinton LA: Global trends in breast cancer incidence and mortality 19731997. Int J Epidemiol 2005;34:405-412.

[3] Guerrero VG, Baez A.F, Cofré- González CG, MiñoGonzález, CG Monitoring modifiable risk factors forbreast cancer: an obligation for health professionals, Rev PanamSalud Publica. 2017; 41:80.

[4]Maric P, Ozretic, P, Levanat, S.; Oreskovic, S.; Antunac, K ‘BeketicOreskovic, L. Tumor markers in breast cancer evaluation of their clinical usefulness, Coll Antro. 2011;35(1):241-7.

[5] Roskoski RJR .The ErbB/HER family of protein-tyrosine kinases and cancer. Pharmacological Research .2014; 79 :34-74. [6] Mori S, Mori Y, Mukaiyama T, Yamada $\mathrm{Y}$, Sonobe $\mathrm{Y}$, Matsushita $\mathrm{H}$, et al. In vitro and in vivo release of soluble erbB-2 protein from human carcinoma cells. Jpn J Cancer Res.1990; 81: 489-94.

[7] Majid RA, Hemin AH, Dana, NM, Hazha AM, Michael D. Breast cancer in Iraq is associated with a unimodally distributed 
predominance of luminal type $\mathrm{B}$ over luminal type A surrogates from young to old age. BMC Women's Health. 2017; 17:27.

[8] Alwan NA. Breast cancer: demographic characteristics and clinic pathological presentation of patients in Iraq. East Mediterr Health J. (2010);16: 1159-1164.

[9] Leong SP, Shen ZZ, Liu TJ, Agarwal G, Tajima T, Paik NS, Sandelin K, Derossis A, Cody H, Foulkes WD. Is breast cancer the same disease in Asian and Western countries?. World J Surg. (2010); 34(10):2308-24.

[10]Hortobagyi, G.N, Garza ,Salaza,r J.; Pritchard, K. The global breast cancer burden: variations in epidemiology and survival. Clin Breast Cancer. 2005; 6:391401. doi: 10.3816/CBC.2005. n.043. [PubMed] [Cross Ref] .

[11]Najem, M.M. and Idrees, Y. (2010). Myoepithelial cells, morphological, immunohistochemical and in situ hybridization evaluation techniques in normal, benign and malignant breast lesions.

A Thesis Submitted to the College of Medicine -Al-Nahrain University.

[12]YÜKSEL S, Gülay AU, İkbal Ç, Atilla, B, Sibel ÖG, Neriman A, Ecem E, Gamze VS, Vahit, Ö. A Risk Assessment Comparison of Breast Cancer and Factors Affected to Risk Perception of Women in Turkey: A Cross-sectional Study. Iran J Public Health.2017; 46(3), 308-317.

[13]Mirghafourvand M, Sakineh M-A-C, Parivash A, Pari R. Breast Cancer Risk Based on the Gail Model and its Predictors in Iranian Women. Asian Pac J Cancer Prev. 2016;17 (8):3741-3745.

[14] Darweesh A, Ayman H. Risk Factors of Breast Cancer among

Palestinian Women in North West Bank. Degree of Master of Public Health, Faculty of Graduate Studies. (2009). An-Najah National University, Nablus, Palestine.

[15] Sezer H, Yilmaz M, Gurler H, Koyuncu A. Breast cancer risk factors in Turkey: a hospital-based case-control study. Asian Pac J Cancer Prev.(2011);12, 2317-22.

[16]Laamiri FZ Nadia H, Aicha K, Hassan A, Youness T, Hassna B, Mustapha M, Barkat A. Risk factors associated with a breast cancer in a population of Moroccan women whose age is less than 40 years: a case control study. Pan African Medical J. (2016); 24(19):8784.

[17]DE SM, Senarath U, Gunatilake M, Lokuhetty D. Prolonged breastfeeding reduces risk of breast cancer in Sri Lankan women: a case-control study. Cancer Epidemiol.2010; 34: 267-73.

[18]Isa SA, Riyadh KL, Enas QS. Risk Factors of Breast Cancer among Women: A Sample from Baghdad. Iraqi J. Comm. Med. (2013).

[19]Mahouri K, Dehghani ZM Zare S.(2007). Breast cancer risk factors in south of Islamic republic of Iran: Acase controlstudy. Eastern Mediterranean Health J, vol.13, No.6.

[20]Hill C, Doyon FL. frequency des cancers en France en 2002 et son evolution depuis 1968, Bull. Cancer. 2006; 93:7-11. 
[21] Collaborative Group on Hormonal Factors in Breast Cancer. Breast cancer and hormone replacement therapy: collaborative reanalysis of data from 51 epidemiological studies of 52,705 women with breast cancer and 108,411 women without breast cancer. 1997; 350: 1047-59.

[22]Molina-Montes E, Pérez-Nevot B, Pollán M, Sánchez-Cantalejo E, Espín J, Sánchez M. Cumulative risk of second primary contralateral breast cancer in BRCA1/BRCA2 mutation carriers with a first breast cancer: a systematic review and meta-analysis. The Breast .2014; 23(6):721742.

[23] Leary AF, Hanna WM, van de Vijver MJ, Penault-Liorca F, Ruschoff J, Osamura, R.Y. Value and Limitations of measuring HER-2 extracellular domain in the serum of breast cancer patients. J Clin Oncol. 2009; 27:1694-705.

[24] Carney WP, Bernhardt D, Jasani B. Circulating HER2 extracellular domain: a specific and quantitative biomarker of prognostic value in all breast cancer patients? Biomark Cancer. 2013; 5:31-9. [25] Christianson TA, Joni KD, Yuzhong JL, Ellizabeth ER, Ron H, Edward JK, Gail MC. NH2-terminally truncated HER-2/neu protein: relationship with shedding of th extracellular domain and with prognostic factors in breast cancer. Cancer Res. (1988); 58:5123-9.

[26] Anido J, Scaltriti M, Joan JBS, Belén SJ, Federico RT, José B, Joaquín A. Biosynthesis of tumorigenic HER2 Cterminal fragments by alternative initiation of translation. EMBO J (2006); 25:3234-44. [27]Nunes RA, Harris LN. The HER2 extracellular domain as a prognostic and predictive factor in breast cancer. Clin Breast Cancer. (2002); 3: 125-135: discussion136127.

[28] Tan L-D, Xu Y-Y, Yu Y, Li X-Q, Chen Y. Serum HER2 Level Measured by Dot Blot: A Valid and Inexpensive Assay for Monitoring Breast Cancer Progression. PLoS one. (2011); 6(4): e18764.

[29] Lee SB, Lee JW, Yu JH, Ko BS, Kim $\mathrm{HJ}$, Son BH, Gong G, Lee HJ, Kim SB, Jung KH, Ahn JH, Lee W, Sung J, Ahn SH. Preoperative serum HER2 extracellular domain levels in primary invasive breast cancer. BMC Cancer. (2014); 14:929.

[30]Molina-Montes E, Pérez-Nevot B, Pollán M, Sánchez-Cantalejo E, Espín J, Sánchez M J. Cumulative risk of second primary contralateral breast cancer in BRCA1/BRCA2 mutation carriers with a first breast cancer: a systematic review and meta-analysis. The Breast. (2014); 23(6):721-742.

[31]Bramwel, VH, Doig GS, Tuck AB, Wilson SM, Tonkin KS, Tomiak A, Perera F, Vandenberg TA, Chambers AF. Changes over time of extracellular domain of HER2 (ECD/HER2) serum levels have prognostic value in metastatic breast cancer. Breast Cancer Res Treat. (2009);114(3):503-11. 